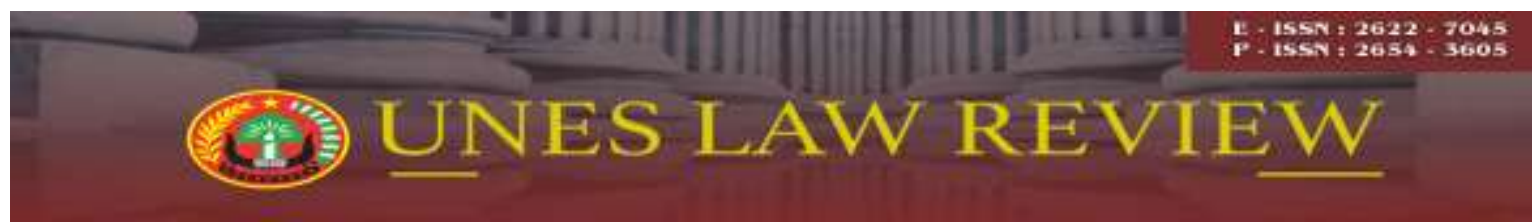

Email: uneslawreview@gmail.com

Online: http://review-unes.com/index.php/law

Volume 2, Issue 1, September 2019

\title{
PENERAPAN SANKSI PIDANA TAMBAHAN PENGGANTIAN KERUGIAN KEUANGAN NEGARA PADA TINDAK PIDANA KORUPSI
}

\author{
Lenny Sefyanda \\ Program Magister Ilmu Hukum, Universitas Ekasakti, Padang \\ E-mail : lennysefyanda82@gmail.com
}

\begin{abstract}
Additional criminal sanctions for compensation for state finances are regulated in Article 18 of Act Number 20 of 2001 concerning Amendments to Law Number 31 of 1999 concerning Eradication of Corruption Crimes. The maximum payment of substitute money is the same as the property obtained from the crime of corruption, so to determine the amount of substitute money must be calculated in advance how much money the state has taken by the defendant for his personal interests. In practice, the provision has been applied by the Judge in the case of corruption in the procurement of clothing and sports shoes at the Payakumbuh City Education Office as in Decision Number 16 / Pid.Sus-TPK / 2015 / Pn.Pdg,
\end{abstract}

Kata Kunci: Pidana Tambahan, Kerugian Negara, Tindak Pidana Korupsi

\section{PENDAHULUAN}

Pada praktik penegakan hukum tindak pidana korupsi, paling tidak ada 2 (dua) ketentuan dalam undang-undang Pemberantasan Korupsi yang sering digunakan, yaitu Pasal 2 ayat (1) dan Pasal 3 Undang-undang Nomor 20 Tahun 2001 tentang Perubahan Atas Undang-undang Nomor 31 Tahun 1999 tentang Pemberantasan Tindak Pidana Korupsi. Pasal 2 ayat (1) menentukan:

"Setiap orang yang secara melawan hukum melakukan perbuatan memperkaya diri sendiri atau orang lain atau suatu korporasi yang dapat merugikan keuangan negara atau perekonomian negara, dipidana dengan pidana penjara seumur hidup, atau pidana penjara paling singkat 4 (empat) tahun dan paling lama 20 (duapuluh) tahun dan denda paling sedikit Rp.200.000.000,- (dua ratus juta rupiah) dan paling banyak Rp. 1.000.000.000,- (satu milyar rupiah)". 
Sedangkan Pasal 3 menentukan:

"Setiap orang yang dengan tujuan menguntungkan diri sendiri atau orang lain atau suatu korporasi, menyalahgunakan kewenangan, kesempatan atau sarana yang ada padanya karena jabatan atau kedudukan yang dapat merugikan keuangan negara atau perekonomian negara, dipidana dengan pidana penjara seumur hidup, atau pidana penjara paling singkat 1 (satu) tahun dan paling lama 20 (duapuluh) tahun dan/atau denda paling sedikit Rp.50.000.000,- (lima puluh juta rupiah) dan paling banyak Rp. 1.000.000.000,- (satu milyar rupiah)".

Perkembangan pelaku tindak pidana korupsi tidak hanya dilakukan oleh orang perorangan atau pejabat instansi tertentu atau oleh penyelenggara negara melainkan meluas hingga mencapai pada masyarakat di luar fungsi pemerintahan serta keberadaan badan hukum sebagai subyek hukum, sehingga merusak sendi-sendi kehidupan bermasyarakat, berbangsa dan bernegara serta membahayakan eksistensi negara. Selain itu, pelaku tindak pidana korupsi juga ditujukan kepada pejabat atau profesi di luar struktur pemerintahan seperti advokat sebagaimana dimaksud dalam Pasal 6 dan pemborong sebagaimana dimaksud dalam Pasal 7 Undang-undang Nomor 20 Tahun 2001 tentang Perubahan Atas Undang-undang Nomor 31 Tahun 1999 tentang Pemberantasan Tindak Pidana Korupsi.

Perbuatan korupsi pada umumnya dapat digolongkan dalam 2 (dua) bentuk atau ruang lingkup yaitu: Administratif corruption (penyalahgunaan kewenangan) dan Against the rule of coruption (Penyimpangan terhadap peraturan perundang-undangan).

Pembagian ruang lingkup tersebut berarti korupsi terjadi pada suatu tatanan administrasi tertentu yang berhubungan dengan jabatan, kedudukan atau suatu departemen yang lebih akrab dikenal dengan penyalahgunaan wewenang yang diikatkan dalam suatu proses administrasi. Di samping itu korupsi dapat juga merupakan penyimpangan atau penentangan terhadap peraturan perundang-undangan yang berlaku, dalam hal ini sepenuhnya korupsi merupakan pelanggaran terhadap undang-undang yang berlaku.

Adapun pasal-pasal yang diterapkan oleh Hakim dalam putusan perkara tindak pidana korupsi adalah Pasal 2 ayat (1) dan Pasal 18 Undang-undang Nomor 31 Tahun 1999 tentang Pemberantasan Tindak Pidana Korupsi sebagaimana telah diubah dengan Undangundang Nomor 20 Tahun 2001 tentang Perubahan Atas Undang-undang Nomor 31 Tahun 1999 tentang Pemberantasan Tindak Pidana Korupsi yang berbunyi: 
(1). Selain pidana tambahan sebagaimana dimaksud dalam Kitab Undang-undang Hukum Pidana, sebagai pidana tambahan adalah:

a. Perampasan barang bergerak yang berwujud atau yang tidak berwujud atau barang tidak bergerak yang digunakan untuk atau yang diperoleh dari tindak pidana korupsi, termasuk perusahaan milik terpidana di mana tindak pidana korupsi dilakukan, begitu pula dari barang yang mengantikan barang-barang tersebut;

b. Pembayaran uang pengganti yang jumlahnya sebanyak-banyaknya sama dengan harta benda yang diperoleh dari tindak pidana korupsi.

c. Penutupan Seluruh atau sebagian perusahaan untuk waktu paling lama 1 (satu) tahun;

d. Pencabutan Seluruh atau sebagian hak-hak tertentu atau penghapusan Seluruh atau sebagian keuntungan tertentu, yang telah atau dapat diberikan oleh Pemerintah kepada terpidana.

(2). Jika terpidana tidak membayar uang pengganti sebagaimana dimaksud dalam ayat (1) huruf b paling lama dalam waktu 1 (satu) bulan sesudah putusan pengadilan yang telah memperoleh kekuatan hukum tetap, maka harta bendanya dapat disita oleh jaksa dan dilelang untuk menutupi uang pengganti tersebut.

(3). Dalam hal terpidana tidak mempunyai harta benda yang mencukupi untuk membayar uang pengganti sebagaimana dimaksud dalam ayat (1) huruf $b$, maka dipidana dengan pidana penjara yang lamanya tidak melebihi ancaman maksimum dari pidana pokoknya sesuai dengan ketentuan dalam Undang-undang ini dan lamanya pidana tersebut sudah ditentukan dalam putusan pengadilan.

Dalam praktik, banyak para pelaku tindak pidana korupsi yang subjek hukumnya adalah aparatur sipil negara (ASN) yang mempunyai jabatan maupun kedudukan, sebagaimana yang terjadi pada Dinas Pendidikan Kota Payakumbuh, yaitu Rafdimar, SH (Pejabat Pelaksana Teknis Kegiatan (PPTK) melakukan tindak pidana korupsi, perbuatan mana dilakukan dengan cara dalam tahun anggaran 2010 pada Dinas Pendidikan Kota Payakumbuh tersedia mata anggaran untuk kegiatan Pelaksanaan Identifikasi Bakat dan Potensi Pelajar dalam Olahraga sebesar Rp. 497.823.500.- (empat ratus sembilan puluh tujuh juta delapan ratus dua puluh tiga ribu lima ratus rupiah) berdasarkan Laporan BPKP tentang jumlah kerugian keuangan Negara. Atas perbuatannya tersebut Pengadilan Tindak 
Pidan Korupsi pada Pengadilan Negeri Klas IA Padang berdasarkan Putusan Nomor: 16/Pid.Sus/TPK/2015/PN.Pdg menjatuhkan pidana penjara selama 4 (empat) tahun dan denda sebesar Rp. 200.000.000,00 (dua ratus juta rupiah) subsidair 3 (tiga) bulan kurungan serta menghukum untuk membayar uang pengganti sebesar Rp 257.680.000,00 (dua ratus lima puluh tujuh juta enam ratus delapan puluh ribu rupiah),karena terbukti secara sah dan menyakinkan bersalah melakukan tindak pidana korupsi secara bersama-sama sebagaimana diatur dan diancam pidana dalam Pasal 2 ayat (1) juncto Pasal 18 ayat (1) huruf b Undang-undang Nomor 31 Tahun 1999 sebagaimana yang telah dirubah dan ditambah dengan Undang-undang Nomor 20 Tahun 2001 tentang Pemberantasan Tindak Pidana Korupsi juncto Pasal 55 ayat (1) ke - 1 KUHP.

Berdasarkan latar belakang pemikiran di atas, maka permasalahan yang dibahas dalam tulisan ilmiah ini adalah sebagai berikut:

1. Bagaimanakah penerapan pidana tambahan pengganti kerugian negara oleh hakim pada tindak pidana korupsi dalam Putusan Nomor 16/Pid.Sus-TPK/2015/Pn.Pdg?

2. Bagaimanakah pertimbangan hakim dalam menjatuhkan putusan pidana tambahan pengganti kerugian negara pada tindak pidana korupsi dalam Putusan Nomor 16/Pid.Sus-TPK/2015/Pn.Pdg?

\section{METODE PENELITIAN}

Penelitian ini adalah suatu penelitian yang bersifat deskriptif analitis, yaitu penelitian yang menggambarkan tentang penerapan pidana tambahan pengganti kerugian Negara dan pertimbangan hakim pada tindak pidana korupsi dalam Putusan Nomor 16/Pid.Sus-TPK/2015/Pn.Pdg. Metode pendekatan yang digunakan dalam penelitian ini adalah yuridis normative, yang didukung pendekatan yuridis empiris. Pendekatan yuridis normatif. yaitu pendekatan yang dilakukan dengan cara mempelajari ketentuan-ketentuan dan peraturan perundang-undangan (Soemitro, 1990: 23). Pendekatan yuridis empiris dilakukan dengan cara mengumpulkan semua bahan dan data yang diperoleh dari lapangan yang berhubungan dengan permasalahan yang diteliti. 


\section{HASIL PENELITIAN}

\section{Penerapan Pidana Tambahan Pengganti Kerugian Negara Oleh Hakim Pada Tindak Pidana Korupsi Dalam Putusan Nomor 16/Pid.Sus-TPK/2015/Pn.Pdg}

Penerapan pidana tambahan pengganti kerugian negara oleh hakim Pengadilan Tindak Pidana Korupsi pada Pengadilan Negeri Klas IA Padang berdasarkan Putusan Perkara Nomor 16/Pid.Sus-TPK/2015/Pn.Pdg, menyatakan Terdakwa Rafdimar, SH (Pejabat Pelaksana Teknis Kegiatan (PPTK), karena telah terbukti secara sah dan menyakinkan bersalah melakukan tindak pidana korupsi secara bersama-sama sebagaimana diatur dan diancam pidana dalam Pasal 2 ayat (1) juncto Pasal 18 ayat (1) huruf b Undang-undang Nomor 31 Tahun 1999 sebagaimana yang telah dirubah dan ditambah dengan Undang-undang Nomor 20 Tahun 2001 tentang Pemberantasan Tindak Pidana Korupsi juncto Pasal 55 ayat (1) ke - 1 KUHP, sehingga atas perbuatannya tersebut dijatuhkan pidana penjara selama 4 (empat) tahun dan denda sebesar Rp. 200.000.000,00 (dua ratus juta rupiah) subsidair 3 (tiga) bulan kurungan serta menghukum untuk membayar uang pengganti sebesar Rp 257.680.000,00 (dua ratus lima puluh tujuh juta enam ratus delapan puluh ribu rupiah) ; apabila terdakwa tidak membayar paling lama dalam waktu 1 (satu) bulan sesudah putusan Pengadilan mempunyai kekuatan hukum tetap, maka harta bendanya disita oleh Jaksa dan dilelang untuk negara, jika hartanya tidak mencukupi dipidana dengan pidana penjara selama 1 (satu) tahun.

Berdasarkan penelitian yang penulis lakukan terhadap putusan perkara Nomor 16/Pid.Sus-TPK/2015/PN.Pdg dengan terdakwa Rafdimar, S.H., selaku Pejabat Pelaksana Teknis Kegiatan (PPTK) Dinas Pendidikan Kota Payakumbuh dapat dianalisis sebagai berikut:

1. Dasar pertimbangan hakim dalam memutus perkara tindak pidana korupsi sebagaimana dalam putusan perkara Nomor 16/Pid.Sus-TPK/2015/PN.Pdg dengan terdakwa Rafdimar, S.H., adalah terpenuhinya unsur-unsur tindak pidana korupsi sebagaimana diatur dalam Pasal 2 ayat (1) juncto Pasal 18 ayat (1) huruf b Undangundang Nomor 31 Tahun 1999 sebagaimana diubah dan ditambah dengan Undangundang Nomor 20 Tahun 2001 tentang Pemberantasan Tindak Pidana Korupsi, yaitu terpenuhi dan terbuktinya semua tindak pidana yang didakwakan dengan unsur-unsur sebagai berikut: 
1) Setiap orang;

2) Secara melawan hukum

3) Memperkaya diri sendiri atau orang lain atau suatu korporasi ;

4) Yang dapat merugikan Keuangan Negara atau Perekonomian Negara.

2. Penerapan unsur tindak pidana korupsi pada Putusan Perkara Nomor 16/Pid.SusTPK/2015/Pn.Pdg

Analisis unsur-unsur tindak pidana korupsi yang telah terpenuhi sebagaimana diatur dan diancam Pasal 2 ayat (1) juncto Pasal 18 ayat (1) huruf b Undang-undang Nomor 31 Tahun 1999 sebagaimana diubah dan ditambah dengan Undang-undang Nomor 20 Tahun 2001 tentang Pemberantasan Tindak Pidana Korupsi berdasarkan Putusan Perkara Nomor 16/Pid.Sus-TPK/2016/Pn.Pdg, yaitu sebagai berikut:

a. Unsur " Setiap Orang,

Pada pertimbangannya, hakim mendasarkan pada ketentuan Pasal 1 ayat (3) Undang-undang Nomor 31 Tahun 1999 yang menyebutkan bahwa yang dimaksud dengan setiap orang adalah orang perorangan atau termasuk korporasi dan yang dimaksud dengan korporasi adalah kumpulan orang dan atau kekayaan yang terorganisasi baik merupakan badan hukum maupun bukan merupakan badan hukum.

Selain itu pula dengan mendasarkan pada keterangan saksi-saksi, terdakwa Rafdimar, SH adalah Pejabat Pelaksana Teknis Kegiatan (PPTK) Dinas Pendidikan Kota Payakumbuh hal mana tidak dibantah para terdakwa saat pembacaan Surat Dakwaan, serta didukung oleh Surat Keputusan Kepala Dinas Pendidikan Kota Payakumbuh Nomor 23. A/I08/KP-2010 tanggal 5 Januari 2010, Nomor: 1009/I.08.34/KP-2010 tanggal 13 Maret 2010 tentang Perubahan Surat Keputusan Kepala Dinas Pendidikan Kota Payakumbuh Nomor 23.A/I08/KP-2010 tanggal 5 Januari 2010 tentang Penunjukan Pejabat Pelaksana Teknis Kegiatan SKPD Dinas Pendidikan Kota Payakumbuh Tahun Anggaran 2010, dan terdakwa tidak membantah identitasnya yang serupa dalam surat dakwaan sehingga majelis hakim menyimpulkan bahwa terdakwa adalah seorang manusia yang mempunyai hak dan kewajiban hukum maka jelas ia adalah termasuk orang dalam arti sebagai subjek hukum. Sehingga Majelis Hakim berpendapat bahwa unsur setiap orang sudah 
terpenuhi.

b. Unsur Melawan Hukum

Pada pertimbangannya, hakim memperhatikan pasal demi pasal dalam Undang-undang Nomor 20 Tahun 2001 tentang perubahan Undang-undang Nomor 31 tahun 1999 tentang Pemberantasan Tindak Pidana Korupsi, karena tidak diatur secara tegas apa yang dimaksud dengan pengertian "melawan hukum". Oleh karena itu berdasarkan penafsiran autentik dari penjelasan Pasal 2 ayat (1) undang-undang tindak pidana korupsi, maka yang dimaksud dengan secara melawan hukum adalah mencakup perbuatan melawan hukum dalam arti formil maupun dalam arti materil yakni meskipun perbuatan tersebut tidak diatur dalam suatu peraturan perundangundangan namun apabila perbuatan tersebut dicela karena tidak sesuai dengan rasa keadilan atau norma-norma atau ugeran-ugeran kehidupan sosial dalam masyarakat, maka perbuatan tersebut dapat dipidana.

Selain itu pula berdasarkan keterangan saksi-saksi, alat bukti surat, keterangan ahli, petunjuk dan keterangan terdakwa serta dihubungkan dengan barang bukti, telah terungkap fakta-fakta persidangan bahwa terdakwa selaku Pejabat Pelaksana Teknis Kegiatan (PPTK) Dinas Pendidikan Kota Payakumbuh dalam pelaksanaan pengadaan pakaian dan sepatu olah raga, terdakwa melaksanakan sendiri seluruh tugas dari panitia/tim tersebut, bahkan seluruh kelengkapan administrasi termasuk seluruh berita acara terkait kegiatan tersebut telah dipersiapkan oleh terdakwa dan panitia/tim tersebut hanya diminta oleh terdakwa untuk menandatangani saja

c. Unsur Memperkaya Diri Sendiri atau Orang Lain atau Korporasi

Pada pertimbangannnya, hakim menyatakan bahwa unsur memperkaya diri sendiri atau orang lain atau suatu korporasi bersifat alternatif, oleh sebab itu, cukup dibuktikan salah satu saja, yaitu memperkaya diri sendiri, atau orang lain atau suatu korporasi; dengan mendasarkan pada Keputusan Mahkamah Agung RI No.951/Pid/1982 tanggal 10 Agustus 1982 dan No.275/K/Pid/1983 tanggal 15 Desember 19883 “memperkaya” artinya memperoleh hasil korupsi walaupun hanya sebagian; 
Berdasarkan fakta-fakta yang terungkap dipersidangan yakni keterangan saksi-saksi, keterangan ahli dan keterangan terdakwa sendiri dihubungkan dengan barang bukti yang ditampilkan oleh Jaksa Penuntut Umum di depan persidangan diperoleh fakta bahwa terdakwa dalam pelaksanaannya terdakwa melaksanakan sendiri seluruh tugas dari panitia/tim tersebut, dan memasukan ke dalam rekening pribadinya sehingga bertambahlah jumlah saldo para terdakwa.

d. Unsur "Dapat Merugikan Keuangan Negara atau Perekonomian Negara".

Pada pertimbangannya, hakim menjelaskan bahwa kata "merugikan" adalah sama artinya dengan "menjadi rugi atau menjadi berkurang" sehingga dengan demikian yang dimaksud dengan unsur merugikan keuangan Negara atau perekonomian Negara adalah sama artinya dengan menjadi rugi atau berkurangnya keuangan Negara. Adapun yang dimaksud dengan "keuangan Negara" dan"perkonomian negara" adalah seluruh kekayaan Negara dalam bentuk apapun yang dipisahkan atau yang tidak dipisahkan termasuk didalamnya segala bagian kekayaan Negara dan segala hak dan kewajiban yang timbul karena berada dalam penguasaan, pengurusan dan pertanggung jawaban pejabat lembaga Negara, baik ditingkat Pusat maupun di tingkat Daerah, berada dalam penguasaan, pengurusan dan pertanggung jawaban BUMN/BUMD, yayasan, badan hukum dan perusahaan yang menyertakan modal pihak ketiga berdasarkan perjanjian Negara.

Selain itu yang dimaksud dengan kata "dapat" menurut penjelasan Pasal 2 ayat (1) menyebutkan bahwa ,dalam ketentuan ini kata "dapat" sebelum phrasa "merugikan keuangan Negara atau perekonomian Negara" menunjukan bahwa tindak pidana korupsi merupakan delik formil ,yaitu adanya tindak pidana korupsi, cukup dengan dipenuhinya unsur-unsur perbuatan yang dirumuskan bukan dengan timbulnya akibat. Hal ini sangat penting untuk pembuktian ,dengan rumusan secara formil yang dianut dalam undang-undang ini, meskipun hasil korupsi telah dikembalikan kepada Negara, pelaku tindak pidana korupsi tetap diajukan ke Pengadilan dan tetap dipidana.

Perbuatan para terdakwa telah berpotensi dapat merugikan keuangan negara karena uang perusahaan yang masuk dalam rekening pribadi tersebut tidak seluruhnya merupakan saldo tunggakan kelompok tani melainkan sebagian besar 
digunakan untuk keperluan lain. Berdasarkan pertimbangan tersebut Majelis "unsur telah merugikan keuangan Negara" telah terpenuhi dan terbukti menurut hukum.

3. Terpenuhinya ketentuan Pasal 18 undang-undang pemberantasan tindak pidana korupsi.

Berdasarkan penelitian yang penulis lakukan terkait dengan pertimbangan hakim dalam menerapkan sanksi pidana tambahan berupa pengganti kerugian keuangan negara dalam Putusan Nomor 16/Pid.Sus-TPK/2015/Pn.Pdg, maka dapat dianalisis sebagai berikut:

a. Meskipun Penuntut Umum tidak mempertimbangkan dalam surat tuntutannya mengenai pidana tambahan, namun Majelis Hakim mempertimbangkan mengenai Pasal 18 Undang-undang Nomor 31 Tahun 1999 sebagaimana telah diubah dan ditambah dengan Undang undang Nomor 20 Tahun 2001 tentang Pemberantasan Tidak Pidana Korupsi yang mengatur tentang hukuman tambahan berupa pembayaran uang pengganti.

b. Pada Pasal 18 Undang undang Nomor 20 Tahun 2001 tentang Pemberantasan Tidak Pidana Korupsi disebut secara jelas bahwa pembayaran uang pengganti sebesar-besarnya adalah sama dengan harta benda yang diperoleh dari tindak pidana korupsi tersebut, maka untuk menentukan jumlah besarnya uang pengganti harus diperhitungkan terlebih dahulu berapa uang negara yang telah diambil oleh terdakwa untuk kepentingan pribadinya, sehingga kerugian keuangan negara dapat dibebankan kepada terdakwa;

c. Tindak pidana korupsi merupakan tindak pidana yang merugikan keuangan negara dan pada prinsipnya titik berat pemberantasan terhadap tindak pidana korupsi bertujuan untuk memulihkan keuangan negara (asset recovery) maka sudah sepatutnya diperhitungkan untuk membayar uang pengganti yang besarnya sebanyak-banyaknya sama dengan hasil yang diperoleh dari tindak pidana korupsi tersebut;

d. Sesuai keterangan ahli,dikuatkan dengan surat-surat bukti serta diakui oleh terdakwa, bahwa terjadinya kerugian negara, yang disebabkan karena Mekanisme Nota Pencairan Dana (NPD) sebesar Rp. 257.680.000,00 (dua ratus lima puluh tujuh juta enam ratus delapan puluh ribu rupiah); 
e. Majelis Hakim menemukan fakta bahwa adalah kewajiban Terdakwa mengganti biaya yang menyebabkan timbulnya kerugian negara, karena dalam fakta persidangan tidak ada pihak lain terbukti ikut menikmati uang tersebut.

Menurut penulis, berdasarkan pertimbangan hakim yang telah dianalisis tersebut di atas, maka penerapan sanksi pidana tambahan berupa penggantian kerugian keuangan negara telah tepat karena ketentuan Pasal 18 Undang undang Nomor 20 Tahun 2001 tentang Pemberantasan Tidak Pidana Korupsi telah terpenuhi dari perbuatan terdakwa yang memerintahkan bendahara proyek untuk mentransfer dana pengadaan pakaian dan sepatu oleh raga Dinas Pendidikan Kota Payakumbuh ke rekening pribadinya sehingga menambah jumlah saldo terdakwa.

\section{Pertimbangan Hakim Dalam Menjatuhkan Putusan Pidana Tambahan Pengganti Kerugian Negara Pada Tindak Pidana Korupsi Dalam Putusan Nomor 16/Pid.Sus- TPK/2015/Pn.Pdg}

Berdasarkan hasil penelitian yang penulis lakukan diperoleh penjelasan bahwa pertimbangan hakim dalam menjatuhkan putusan pidana tambahan pengganti kerugian negara pada tindak pidana korupsi terhadap terdakwa berdasarkan Putusan Nomor: 16/Pid.Sus-TPK/2015/Pn.Pdg di Pengadilan Tindak Pidana Korupsi pada Pengadilan Negeri Kelas IA Padang adalah sebagai berikut:

1. Pertimbangan Yuridis, mendasarkan pada:

a. Penetapan Ketua Pengadilan Tindak Pidana Korupsi pada Pengadilan Negeri Padang Nomor 16/Pid.Sus-TPK/2014/PN Pdg tanggal 16 April 2015 tentang penunjukan Majelis Hakim;

b. Penetapan Majelis Hakim Nomor 16/Pid.Sus-TPK/2014/PN Pdg tanggal 20 April 2015, tentang penetapan hari sidang;

c. Berkas perkara dan surat-surat lain yang bersangkutan, antara lain:

1) Dakwaan oleh Jaksa Penuntut Umum, dimana dalam perkara ini, terdakwa didakwa di depan persidangan oleh Penuntut Umum dengan dakwaan berlapis, yaitu dakwaan primer, terdakwa diduga melanggar Pasal 2 ayat 1 juncto Pasal 18 ayat (1) huruf b Undang-undang Nomor 20 Tahun 2001 tentang Perubahan Atas Undang-undang Nomor 31 Tahun 1999 tentang Pemberantasan Tindak Pidana Korupsi juncto Pasal 55 ayat (1) ke-1 KUHP, dan dakwaan subsider yaitu 
terdakwa diduga melanggar Pasal 3 ayat (1) juncto Pasal 18 ayat (1) huruf ,b Undang-Undang Nomor 20 Tahun 2001 tentang Perubahan Atas Undang-undang Nomor 31 Tahun 1999 tentang Pemberantasan Tindak Pidana Korupsi juncto Pasal 55 KUHP;

2) Tuntutan pidana (requisitoir) dari Penuntut Umum yang dibacakan dan diserahkan di persidangan, dimana dalam perkara ini, Penuntut Umum menuntut terdakwa: supaya Majelis Hakim Pengadilan Tindak Pidana Korupsi Pada Pengadilan Negeri Padang yang memeriksa dan mengadili perkara ini memutuskan :

a) Menyatakan terdakwa Rafdimar, SH terbukti secara sah dan menyakinkan bersalah melakukan tindak pidana korupsi secara bersama-sama sebagaimana diatur dan diancam pidana dalam pasal 2 ayat (1) jo pasal 18 ayat (1) huruf b UU No.31 Tahun 1999 yang telah dirubah dan ditambah dengan Undang-Undang Nomor 20 Tahun 2001 tentang Pemberantasan Tindak Pidana Korupsi jo pasal 55 ayat (1) ke - 1 KUHP dalam dakwaan Primair;

b) Menjatuhkan Pidana terhadap terdakwa Rafdimar, SH dengan pidana penjara selama 6 (enam) tahun dan 6 (enam) bulan dikurangi selama mereka terdakwa dalam tahanan sementara dan denda sebesar Rp. 200.000.000,00 (dua ratus juta rupiah) subsidair 6 (enam) bulan kurungan dengan perintah mereka terdakwa tetap ditahan;

c) Menghukum terdakwa Rafdimar, SH untuk membayar uang pengganti sebesar Rp. 427.825.317,00 (empat ratus dua puluh tujuh delapan ratus dua puluh lima ribu tiga ratus tujuh belas rupiah) apabila terdakwa tidak membayar paling lama dalam waktu 1 (satu) bulan sesudah putusan Pengadilan mempunyai kekuatan hukum tetap, maka harta bendanya disita oleh Jaksa dan dilelang untuk negara, jika hartanya tidak mencukupi dipidana dengan pidana penjara selama 3 (tiga) tahun 3 (tiga) bulan;

d) Menyatakan barang bukti berupa: seluruh barang bukti dikembalikan kepada Jaksa Penyidik Kejaksaan Negeri Payakumbuh untuk dipergunakan dalam perkara lain; 
e) Menetapkan supaya terdakwa Rafdimar, SH membayar biaya perkara sebesar Rp5.000,00 (lima ribu rupiah).

2. Pertimbangan Terhadap Fakta di Persidangan, didasarkan pada:

a. Pemeriksaan Saksi-saksi (a charge)

Dalam perkara ini, majelis hakim telah melakukan pemeriksaan terhadap saksi-saksi yang diajukan Penuntut Umum yang berjumlah 29 (dua puluh sembilan) orang saksi di bawah sumpah, yaitu: saksi Drs. Edvianus, Drs. Ridwan Djanur, Drs. Ruswan Atra, Deswita Darnis, Lakon Siska, Basnaidi, Andri Eka Putra, Syaflinda Irwansyah,S.Pd, Kasril Kamil,SH,MSi, Sospidarmi, Ridha Kurniadi, AMd, Masri, Darfizon, Muzbar, Zulkarnaini, Zulfitri, Jusniwarti, Tavril Samry, SPd, Teti Warni, Netti Herawati, Erman, S.Pd, Dra. Zirmalena, Nurhaza, SH, Jafrinal Arifin, SH,MSi, Saksi Efrial, S.Sos, Evizal Karisfa, Berry Bima, SPd, dan Andri Yunidal, SE. Terhadap keterangan saksi-saksi tersebut terdakwa membenarkannya.

b. Pemeriksaan Ahli di Persidangan

Dalam perkara ini ahli yang didatangkan untuk kepentingan pembuktian tindak pidana korupsi adalah Joko Susanto, AK, CA, Auditor BPKP Provinsi Sumatera Barat, yang mengatakan bahwa: "Pada intinya bahwa terjadi nya kerugian negara, disebakan oleh: PPTK tidak menyiapkan bukti-bukti pengeluaran dengan benar, dan Kuasa Pengguna Anggaran juga tidak menguji bukti-bukti pengeluaran dengan benar, serta Pejabat Pengguna Anggaran yang tidak menguji bukti-bukti pengeluaran yang menjadi pendukung SPM dengan benar sebagaimana diatur dalam Peraturan Menteri Dalam Negeri Nomor 13 Tahun 2006 tanggal 15 Mei 2006 tentang Pedoman Pengelolaan Keuangan Daerah, sehingga ketiga pihak ini merupakan pihak-pihak yang bertanggung jawab atas terjadi nya kerugian Negara"

c. Pemeriksaan Terdakwa di Persidangan

Dalam persidangan Terdakwa mengakui dan tidak membantah, tentang hasil kerugian Negara yang disampaikan ahli Joko Susanto dipersidangan, yang didukung oleh dokumen Laporan Hasil Pemeriksaan Audit Investigatif Badan Pengawasan Keuangan dan Pembangunan (BPKP Perwakilan Sumatera Barat) tanggal 17 Maret 2015, akibat terjadi penyimpangan yang dilakukan oleh Terdakwa, terjadi kerugian Negara, sejumlah Rp257.680.000,00 (dua ratus lima 
puluh tujuh juta enam ratus delapan puluh ribu rupiah). sesuai dengan keterangan ahli dipersidangan yang didukung oleh Laporan Hasil Audit Dalam Rangka Penghitungan Kerugian Negara.

d. Pemeriksaan Barang Bukti di Persidangan

Sesuai keterangan ahli, dikuatkan dengan surat-surat bukti serta diakui oleh terdakwa, bahwa terjadi nya kerugian Negara, yang disebabkan karena Mekanisme Nota Pencairan Dana (NPD) sebesar Rp257.680.000,00 (dua ratus lima puluh tujuh juta enam ratus delapan puluh ribu rupiah); Terhadap barang bukti di atas, terdakwa telah membenarkannya dan demikian juga saksi-saksi telah membenarkan kalau barang bukti tersebut dibuat oleh terdakwa.

e. Terpenuhinya Unsur-unsur Pasal yang Didakwakan Penuntut Umum.

Dalam perkara ini, berdasarkan fakta-fakta hukum di persidangan, Majelis Hakim telah membuktikan dakwaan Penuntut Umum,yaitu dakwaan primer sebagaimana diatur dalam Pasal 2 ayat (1) Jo Pasal 18 ayat (1) huruf a, huruf b, ayat (2) dan ayat (3) Undang-Undang Nomor 31 Tahun 1999 yang telah diubah dan ditambah dengan Undang-Undang Nomor 20 Tahun 2001 tentang Perubahan atas Undang-Undang Nomor 31 Tahun 1999 tentang Pemberantasan Tindak Pidana Korupsi yang mempunyai unsur-unsur sebagai berikut : Setiap orang, secara melawan hukum, Melakukan perbuatan memperkaya diri sendiri atau orang lain atau suatu korporasi, dapat merugikan keuangan negara atau perekonomian negara.

3. Pertimbangan Non Yuridis

Majelis hakim yang memeriksa perkara tindak pidana korupsi, sebelum menjatuhkan pidana terhadap terdakwa, Majelis Hakim berpendapat perlu untuk mempertimbangkan mengenai beberapa aspek, baik yang berkenaan dengan diri terdakwa sendiri maupun yang berkenaan dengan perbuatan terdakwa sebagai pertimbangan non yuridis, yaitu pertimbangan hakim yang didasarkan pada kondisikondisi yang melatarbelakangi terdakwa secara psikhis dan sosiologis serta sikap terdakwa di persidangan.

Pertimbangan non yuridis yang digunakan majelis hakim sebagai alasan dalam menjatuhkan pidana terhadap terdakwa tindak pidana korupsi di Pengadilan Tindak Pidana Korupsi pada Pengadilan Negeri Kelas IA Padang adalah: 
a. Hal yang Memberatkan, yaitu: perbuatan terdakwa tidak mendukung program pemerintah dalam Pemberantasan Tindak Pidana Korupsi.

b. Hal-hal yang meringankan, yaitu:

1) Terdakwa jujur dan mengaku terus terang atas perbuatannya sehingga memperlancar jalannya persidangan.

2) Terdakwa berlaku sopan di persidangan.

3) Terdakwa menyesali perbuatannya dan berjanji tidak akan mengulangi lagi.

4) Terdakwa belum pernah dihukum.

5) Terdakwa telah lama mengabdi sebagai Pegawai Negeri.

\section{PENUTUP}

Berdasarkan pembahasan sebagaimana yang telah dipaparkan di atas, maka penulis dapat menarik kesimpulan sebagai berikut:

Penerapan pidana tambahan pengganti kerugian negara oleh hakim pada tindak pidana korupsi dalam Putusan Nomor 16/Pid.Sus-TPK/2015/Pn.Pdg sudah tepat, karena didasarkan pada, pertama, terpenuhinya unsur-unsur Pasal 2 ayat (1) undang-undang pemberantasan tindak pidana korupsi, yaitu unsur setiap orang, unsur secara melawan hukum, unsur memperkaya diri sendiri atau orang lain atau suatu korporasi dan unsur yang dapat merugikan keuangan negara atau perekonomian negara dan kedua, terpenuhinya ketentuan Pasal 18 ayat (1) huruf b, Undang-Undang Nomor 20 Tahun 2001, bahwa pembayaran uang pengganti sebesar-besarnya adalah sama dengan harta benda yang diperoleh dari tindak pidana korupsi sehingga terdakwa berkewajiban untuk mengganti, karena tidak ada pihak lain terbukti ikut menikmati uang tersebut.

Pertimbangan hakim dalam menjatuhkan putusan pidana tambahan pengganti kerugian negara pada tindak pidana korupsi dalam Putusan Nomor 16/Pid.SusTPK/2015/Pn.Pdg ada 3 (tiga) yaitu: pertama, pertimbangan yuridis, meliputi: Penetapan Ketua Pengadilan Tipikor tentang Penunjukan Majelis Hakim yang memeriksa dan mengadili perkara, Penetapan Majelis Hakim tentang penetapan hari sidang; surat dakwaan Penuntut Umum, tuntutan pidana (requisitoir) dari Penuntut Umum, kedua, pertimbangan terhadap fakta di persidangan, meliputi: pemeriksaan saksi-saksi, pemeriksaan terdakwa, pemeriksaan barang bukti, terpenuhinya unsur-unsur pasal yang didakwakan, dan ketiga, 
pertimbangan non yuridis, meliputi: pertimbangan hal-hal yang memberatkan dan:hal-hal yang meringankan pada diri terdakwa.

\section{DAFTAR PUSTAKA}

\section{Buku Teks :}

Bohari. Hukum Keuangan Negara. Tanpa Penerbit. Makassar, 2006

Darwan Prinst, Pemberantasan Tindak Pidana Korupsi, PT. Citra Aditya Bakti. Bandung, 2002

Djoko Prakoso. Kejahatan-kejahatan yang Merugikan Negara, Bina Aksara, Jakarta, 1987

Eddy O.S. Hiariej, Teori dan Hukum Pembuktian, Penerbit Erlangga, Jakarta, 2012

Fajar Prajitno, Pengantar Pengadaan Barang/Jasa Pemerintah dalam Modul Pengantar Pelaksanaan Pengadaan Barang dan Jasa di Indonesia, Lembaga Kebijakan Pengadaan Barang dan Jasa (LKPP), 2013

IGM. Nurdjana. Korupsi Dalam Praktek Bisnis Pemberdayaan Penegak Hukum, Program Aksi dan Strategi Penanggulangan Masalah Korupsi, PT. Gramedia Pustaka Utama, Jakarta, 2005

Ilham Gunwan Postur Korupsi di Indonesia, Tinjauan Yuridis Sosiologis, Budaya, dan Politis, Angkasa, Bandung, 1993

Jimly Assidiqie dan M. Ali Syafaat, Teori Hans Kelsen tentang Hukum, Sekretariat Jenderal (Setjen) Mahkamah Konstitusi Republik Indonesia, Jakarta, 2006

Nogi Hessel Tangkilisan, Manajemen Publik. PT. Gramedia Widiasarana Indonesia, Jakarta. 2005

P.A.F. Lamintang, Dasar-Dasar Hukum Pidana Indonesia, PT Citra Aditya Bakti, Bandung, 1997

Syed Hussain Alatas, Korupsi: Sifat, Sebab dan Fungsi, LP3ES, Jakarta, 1987

\section{Peraturan Undang-Undang :}

Undang-Undang Nomor 31 Tahun 1999 tentang Pemberantasan Tindak Pidana Korupsi

Undang-Undang Nomor 20 Tahun 2001 tentang Pemberantasan Tindak Pidana Korupsi. 